\title{
American and Chinese Literature. Behind the Mask of Postmodernism: a National Failure
}

\author{
Alberto Castelli* \\ Hainan University \\ China
}

Received 01.05.2018, received in revised form 23.05.2018, accepted 06.06.2018

\begin{abstract}
The article is less an investigation of American, and Chinese postmodern fiction from a comparative perspective, than it is an acknowledgement of postmodern fiction as a representation of national failure. Besides the well-known attributes of black humour, fantasy and dreams, fragmentation, metafictional elements, intertextuality, parody, radical irony, literature lavishes a violent attack on what, at different degrees, could be understood as a postmodern society. The aesthetic of social protest such as deviant sexuality, drug and alcohol addiction (America), and expressions of insanity, historical decadence (China) are to be read as the sense of tragedy binding tightly two civilisations never so similar at any stage in history.
\end{abstract}

Keywords: american dream, cultural revolution, maoism, post-modernity, postmodernism.

DOI: 10.17516/1997-1370-0279.

Research area: philology.

\section{Postmodern Dynamics}

Let us imagine for a while that Raskolnikov is lying sick on his couch of poverty, using old clothes as a pillow, just after plotting the murder of the old pawnbroker for the common goods, but before committing it received a letter with a considerable monetary donation for his previous merits as a student. Suddenly his about-tocommit murder would appear as a moral heresy, and he might as well abhor his previous plot to become a writer searching for god or money. Let us assume for Sisyphus the possibility to have his eternal recurrence interrupted. The evolution of humanity in the face of tragedy would be for Sisyphus, while enduring the eternal punishment of his meaningless state, to meet a child. Let us frame that each time he pushes the insignificant stone, a child is waiting for him at a different time and space of the slope. He would start caring for the child; inevitably, because of the child, the punishment would assume some degrees of relevance, not least a never discovered secret between Sisyphus and God. Truly, the myth would assume new proportions, the moment humans become acclimated to the conditions of punishment, humiliation and debasement, the absurdity of life can be transformed from passive acceptance to a beautiful significance. At last, why not let us consider the puppet of Orestes at its climax. When the marionette representing

(C) Siberian Federal University. All rights reserved

* Corresponding author E-mail address: lamezzapunta@yahoo.com 
Orestes is about to avenge his father's death on Aegisthus and his mother Clytemnestra, someone suddenly might tear a hole in the paper sky over the stage. Orestes, Pirandello beautifully suggests, at first so determined to live by his values, in other words, would become Hamlet, troubled and indecisive to an extent to forget the source of his action. Tout-court this is what postmodernism does, it explains the tragedy by ignoring it.

The Great War had taught writers including Hemingway, Erich Maria Remarque, Camus that the world was a fatality of trenches and nothingness. A Farewell to Arms, All Quiet on the Western Front, The Myth of Sisyphus introduce within the possibility of modernism a definite element, the crisis of reason. Modernism's look towards the future is a mix of fear and hope; there is the desolation of the war, shouldered by a metaphysical involvement referring to divine or art as a moment of escape. In point of fact, within the frames of modernism salvation is still possible; it is a blurred zone between art and destruction. But in the post-WWII age, the modernist characters are dead in rivers of blood; art becomes finally irrelevant. Postmodernism has met the limit of reason; tragedy has sublimated the theory by materialising in Auschwitz, not an aberration, but the logical consequence of the modern project. Postmodernism is then the last step forward into nihilism. On the ruins of modernity, it does not construct society anymore, it deconstructs the past attainment, it duplicates, it clones, it pastes piles of models in a collage of images that pretends to be original, it does look into the future but while waiting for annihilation. And it does it with irony and cynicism, parodying life and treating death as a game for dumb. Modernism, viewing it as a crisis of consciousness, carved a frame bigger than life. It casts a light deep into life's mysteries without superstitious prejudice, it becomes comprehensibly blaspheme and arrogant. Of course, it does, it carries man's ultimate questions and the deception of a generation who has no answers. It refuses the safe scheme of the realist tradition offering an alternative object that does not explain what it represents but hints another beauty and a different order for those who will never die. Contrary, postmodernist is a depthless response to the inevitable. It is not interested in offering solutions because postmodernism does not have any. It does not solve the tragedy it takes it for granted, it has learnt how to live with natural disasters and the threat of a nuclear moment. It does not suggest alternative beauty or reachable peace, but it toys with the shallowest aspect of contemporaneity, consumerism and daily issues. It waits for the end for those who will die tomorrow. As much fascinating the debate is, I will not enter it more than what I already did. ${ }^{1}$ Surely there has been a breaking point where the architecture of Robert Venturi and Philip Johnson has taken over the International Style of Le Corbusier. Ornament and decorative façade diverge from the boxy, flat, functional office towers of modern architecture, the novels of Pynchon and DeLillo substitute the great narrative of Dostoyevsky and Mann, the consumerist art of Warhol replaced the anxiousstricken expressionists painters. Indeed, there has been a radical break between the end of the 1950s and the beginning of the 1960s, European scholars such as Foucault gave it a philosophical status, John Barth's essays describe it as a literary movement, critics such as Jameson, Cohen, Lyotard diagnose the cultural and political derive. Abstract expressionism, existentialism, all in all, the high-modernist impulse comes to an end, edited by Andy Warhol's pop art, punk, and experimental cinema. Theory, sociological, anthropological, philosophical, linguistic, ride the waves of an unexpected rupture. In the 1960s Structuralism interrupts the last four centuries of domination of an autonomous subject, replacing it with the structure, rules, codes, functions, 
social phenomena. Modern theory, ranging from the rationalism of Descartes, through the bravery of the Enlightenment until the social theory of Marx, Weber and Durkheim is under attack. The fault, Postmodernism claims, is to have claimed universal truth through an all-inclusive approach covering theory and experience and to have believed in the inner connection between reason and freedom. Postmodern theory stands as a step above chaos, offering a much more flexible position in favors of indeterminacy, plurality, and partiality. In advanced capitalist society, as Weber and Simmel had foreseen, the increased of rationalization has meant the enlarging of the public-bureaucratic sphere at the expenses of individual freedom, thus the modern dialectic reason-freedom must be rejected. Neither Kant nor Freud nor Marx, but the deconstructionism of Derrida is the leading moment entering the picture of the new modernity.

For the Western civilisation, and not just, the Holocaust, point-blank, marks the failure of the project of Enlightenment, and if we want to see in the Eighteen-century the beginning of modernity, Auschwitz went down in history as the end of it. The death of God, the second one, that one yelled by the insane philosopher of Zarathustra and the other, that one rationally perpetuated in the hell of the concentration camps, is the historical push for a snowball of intellectual endings heading inexorably to a postmodern dimension and its prophets. Somewhere along the line, if Postmodern is post-Auschwitz, it is not unfair to say that, considering Maoism as the experience of Chinese modernity, postCultural Revolution is surely the first moment of Chinese postmodernity. ${ }^{2}$ In reference to China, it is the Cultural Revolution what undermined, annihilated, the Chinese project of modernity establishing a political reality whose excess went far beyond reason. 'The most profound destruction lies not only in the physical victimisation but also in psychic traumatisation, which deprived the nation of its faith in historical truth and the ethical good'. ${ }^{3}$ Accordingly, Paul Pickowicz and Zhang Xudong to that of postmodernism seem to prefer the term postsocialism, highlighting the national historical lineage, a moment of rupture and continuity with the past, and the social, economic configuration of contemporary China. The definition would be suitable if it were not for the fact that it is a political definition dragging ideology into an age allegedly ideology-free. We are back to square one, and we shall deal with it. The mistake is the intellectual tendency to refer to postmodernism within the architecture of postindustrial contexts (Jameson, 1991), as to say to make of it a cultural consequence of an economic rank. Postmodernism in China is many things, first of all, a historical periodisation. Coming next, Mao's death and the fall of the Gang of Four, the past decades witnessed massive happenings in China: the economic reforms being just one of those. These also include the military crackdown on the students protest at Tiananmen Square (1989), Deng Xiaoping's last major political act the Southern Tour and the formalisation of 'socialist market economy' (1992). These were followed by the recovery of Hong Kong (1997) and Macau (1999), the entry of China into the World Trade Organization (2001), and the Olympics games (2008). Thus, if we were to make of Chinese postmodernism a historical-periodizing concept, post-1976 would be correct, but post-1989 Tiananmen would be better, because of what Tiananmen represents in the people-state dynamics, and because it is only after the Tiananmen massacre that the urban fiction develops into a post-utopian subjectivity. Postmodernism then is ascribed to the historiccultural reality left in heritage by the Maoistera, which is altogether post-revolution, postcolonialism, post grand-narrative, post-utopian, the blend of post that shapes the maze of Chinese 
contemporaneity. In the $80 \mathrm{~s}$, when the tragic dimension of the Cultural Revolution was not unfolded yet, but the consequences were quite evident, China waved the flag of postmodernism as much as the May Fourth generation waved that of the Enlightenment. But the adjustment from modernity to postmodernity was not going to be free of charge. Ci Jiwei's thesis is that of a dramatic shift from the utopianism of Mao-era (ascetic, self-denying excess) to the hedonistic, narcissistic excess of the post-Mao period, postsocialist era. Following Ci Jiwei's lead, it is possible to argue that the decadent, sensual, excesses of the present are best understood as the logical result of failed Maoist asceticism. Once more Pickowicz provides a sociological key:

Once the ascetic self-denial modes of the revolution were rejected, the hedonism of the modern global enemy imagined by Maoism was embraced with passion. Thus if anything is to blame for the soullessness, emptiness, and directionlessness of many of the urban youth (...) it is not globalisation, it is the excess of Maoism. In brief, one excess gives rise to another ${ }^{4}$.

My understanding is that Chinese postmodernity is the implosion of Maoist civilisation, a space of struggle between the residual of the socialist past and the illusion of the present. Here is where an additional version of Chinese postmodernism establishes itself: after the economic theorem and the historical periodisation, it is the time of aesthetic practices. The horrors of the past (Maoism) and the violence of the post-Maoist regime (Tiananmen, 1989) generates a general condition of alienation and disillusionment fused with a not well-defined sense of nostalgia. Aiming to deal with the present critically, a sentimental retrospection over whatever past epoch, Shanghai in the 1930s or the Liberation time, pervades the lyrics of both male and female writing. More than that, postmodernism develops into an aesthetic moment of differentiation, division, disaggregation, disintegration of patriarchal communism, virtually the secularisation of Chinese society. Under these circumstances, by questioning the very nature of real writers overturned centuries of sediment, official, truth: the male society, patriarchal society, the violence of the past, the brutality of dictatorship, the white elite, the Western elite. Back to the comparative approach, my intellectual challenge here will not be that of paralleling two different versions of postmodernism, but that of closing the gap between them. The state of unhappy consciousness for the scattering into fragments of the American dream and the existential waves put in motion by the excesses of Maoism, walk along together on the same violent path. This so-called postmodern violence I refer to is not so much spatial as it is temporal, it is the empty spiritualism and delusion permeating American post-America Dream fiction as it does in Chinese post-Maoist fiction. To be plain, violence associated with contemporary narrative is more psychological than physical, less ontological than it is historical. It is an opaque zone of hesitation where men are turned into their obsessions and obsessions become the landscape. It goes without saying that the theoretical background remains the idea of nation crumbling into pieces. I intend to move gradually towards the point using a few novels as examples, in short, it is the mediocrity of contemporaneity to be violent. The terror, the threat of annihilation which reminds of Camus's, Sartre's perception of human being in disequilibrium with the cosmos, are somewhat resolved in the dramatic lyric of Fitzgerald and in the haunted vision of Chinese Avant-garde.

\section{The Sand Castle}

\section{of the American Dream}

The first generation of American Postmodernist writers have been educated by the 
slaughter of thousands; they came through a war even more disturbing than the first, World War II robbed millions of people of their youthful innocence. Salinger was twenty-five years old when he landed at Utah Beach in 1944, and one year later he entered Dachau. Fitzgerald dropped out of Princeton and took a commission as a second lieutenant in the army. Luckily for him, the armistice was signed few months before being shipped overseas. Same fates share the fictional protagonists. Gatsby, among many other masks, was a soldier in Europe. The second part of Updike's Rabbit Run opens on the garden of Mrs Smith, where Rabbit is now working as a gardener. The widow tells him that her son died in a war satisfying to win (WWII). As many American soldiers in the 1950s, Seymour, Franny's oldest brother, in Salinger's Franny and Zooey, committed suicide victim of a posttraumatic stress disorder. Paul Austen belongs to the second postmodernist generation, yet Moon Palace spins around the first half of the Twentieth century. Mrs Hume (Effing's carer), on her days off, goes to visit her brother Charlie at the V.A. Hospital in the Bronx without forgetting to bring along some chocolate. Once a bomber pilot during the Second World War he is now thought not to be 'right in the head'. And it is just after victory that the soldiers, the civilians, the writers, the characters, began to deal with the uncomfortable meeting between war and peace, and they fight to realise what it was actually asked to them of them. In this direction, World War II is a turning point in history from which will emerge the second half of the century. While after the war England would be returning to her insular isolationism, Eastern Europe would fall under the political and military influence of the Soviet Union. It became clear by now that back in 1943, not to open a third front on the Eastern front, as Churchill had advised, cost the whole world the cold war. European society was again engaged in reconstruction, Western Europe in a few years will produce a fascinating coming back, but the bulk of power had shifted elsewhere. America awoke certain of her international role, though American society swayed between the Cold War and juvenile delinquency, the dream of democracy and the threat of Communism. Not surprisingly in the $60 \mathrm{~s}$ and $70 \mathrm{~s}$ the contradiction of advanced capitalist societies gave lead to new cultures and modes of thought, new civil rights, gay and feminist protest, ecology groups, questioning modern practice, utterly an enlarged civil space. New social theories emerged questioning the consumer society, the value of mass culture, the inevitability of urbanisation changing the face of everyday life. It is the postmodern turn. The menacing threat of the Cold War largely contributed to create a conservative and conformist America, people's suspicious of any connection with communism forced America to shield itself within domestic walls (McCarthyism) and to engage in overseas conflict (Korea, Vietnam). By enjoying the economic prosperity and high standard of living, most people were satisfied with what they had and mostly did not protest against the growing contradictions in the US. In fact, it is as well a reactionary America fighting against nuclear weapons and armaments, for ecological awareness, against the white dominant logic. It is the America of Civil Rights movement in the decades $50 \mathrm{~s}-60 \mathrm{~s}$, enraged by racial, ethnic, gender and sexual inequality. The America represented by global leaders such as Martin Luther King assassinated in 1968, Malcolm X killed in 1965, the pro-democratic and less conservative President John Kennedy shot dead in Dallas in 1963, and his brother, Senator Robert Kennedy, murdered in 1968. Ad nauseam the position of literature in American has been discussed: American society on the age of mass consumerism, American's lack of individual's privacy, America with no tradition, 
America with no enough past to define itself. Inspiringly, William Barrett has to write in 1951 that American society lacks that tragic sense of life that Russian and European writers demand in exchange for identity: "our extrovert civilisation has developed other means of adjusting to life without their spiritual struggles". ${ }^{5}$ Postmodern American narrative took then a different turn than that of European existentialist grief. Better than traditional Realistic, Naturalistic or more established Modernist novels, it depicted the spirit of the period by narrating the outskirts episodes of chaotic urban setting, disintegration of moral values, absurdity, radical rebellion, nihilism, sexuality, alcoholism, slang and jargon expressing a rebellion against standard norms (Salinger). No mystery then if the changing relationship between the individual and the whole are material for a new concern. Postmodern novels display the unforeseeable possibilities of human conditions when at stake there are no longer the conditions of existence, but existence itself. At last Bertrand Russell's prediction was proved correct, 'I' became no more than a grammatical expression.

It all started with the American Dream, the idea that people are always reaching towards something greater than themselves, 'life liberty and the pursuit of happiness'. A cultural credo whose sociological roots are somewhere between a 'Napoleon complex' and Victorian morality, and whose pragmatism lies in class mobility and ideal family. The Great Gatsby turns out exquisitely as a representative case. Written in 1925, the novel serves as a bridge between World War I and the Great Depression of the early 1930s. What we have all around is the glamour of the Jazz Age, the 'Roaring Twenties' and indeed the failure of the American Dream. Gatsby is a truly American character, a firm believer in the American Dream of self-made success: he has, after all, not only invented and self-promoted a whole new persona for himself but has raised both financially and socially from his initial condition. The American Dream then of the post-war generation or of those who arrived in America with the promise of future in their pocket,

For a transitory enchanted moment, man must have held his breath in the presence of this continent, compelled into an aesthetic contemplation he neither understood nor desired, face to face for the last time in history with something commensurate to his capacity for wonder. ${ }^{6}$

is entangled with Gatsby's dream, that of amassing a vast fortune to win the affections of the upper-class Daisy.

He knew that when he kissed this girl and forever wed his unutterable visions to her perishable breath, his mind would never romp again like the mind of God?

And with ours as well:

Tomorrow we will run faster, stretch out our arms farther... and one fine morning we beat one, boats against the current, borne back ceaselessly into the past. $^{8}$

But Nick, the narrator who lives across the lawn from Gatsby, knows too well that green is the light across the water at the end of Daisy's dock, green are Daisy's eyes, and green is the colour of money. The American dream is in fact based as well, if not chiefly, on the belief of the possibility of happiness through material success. Inevitably the idealism of the Founding Fathers has mutated into market ideology, 'life, liberty and the pursuit of happiness' has become a choice about where one plays golf or what shirts to wear. We know that Daisy and Tom have spent a year in France without a particular reason, drifting here and there playing polo. We are given a detailed description of the majesty of Gatsby's house, made of marble steps, Marie Antoinette music-rooms and Restoration salons, filled with champagne, Rolls-Royce, servants, orchestras, 
lights and gipsies. Subsequently, the materialism of the age reflects on the personality of the characters. Daisy's love for Gatsby, for instance, does not have the same tragedy that pushed him above his destiny. To her, Gatsby is no dream at all, just a memory. Thus, her alleged love is not the expression of regrets and hopes, but another misjudgment of her superficiality. Following, after life has brought them together once more, she does not cry when she sees him, but at the display of his wealth. It is the sight of his silk and fine flannel shirts what brings down the wall of her indifference. We might as well leave love aside and replace it with aesthetic pleasure to describe Daisy's feelings. He bought a palace just to be across the bay from where she lives; more shallowly she likes him, he looks cool to her green eyes because he resembles the advertisement of Doctor T. J. Eckleburg on the giant billboard. For well Gatsby decoded the ghastly secret behind her mortal beauty, her voice alike her dreams and choices is 'full of money'. Alike post-French Revolution Europe, the hollow pursuit of wealth and social status is the real tragedy in The Great Gatsby, at large in American society. Fitzgerald's wisdom reverses on a pessimistic judgment over his characters, 'careless and confused' and his age, split into two classes, the old elite and the new self-made man. No matter how shining Gatsby's wealth is, it will never buy himself a social niche in East Egg. This is why he dies while the Buchanans live on. Each character has their own way of showing off their wealth and status, fancy cars (Tom's blue coupe and Gatsby's RollsRoyce), lavish mansions, convenient marriage, the American Dream proved itself at the edge of collapse. Gatsby's bonds are counterfeit, part of his fortune comes from merchandising illegal liquors, his success then is stained by corruption. So it is for Jordan Baker, who won her first golf tournament by cheating in the game. Let alone the countless episodes of adultery, Tom on
Daisy, Daisy on Tom, Myrtle Wilson on George Wilson. The pursuit of happiness imprinted in the American Declaration of Independence became, in the end, an empty pursuit of pleasure, decaying of social and moral values, cynicism, and greed. Gatsby's undeserving ending, the whole indifference before his burial, maintains tones of Wagnerian epic mysticism: it is Fitzgerald raising him up above the rubble of the American Dream.

John Updike's Rabbit Run is again the personification of the American Dream, that would be the atavistic need for people to have something to believe in. A former high school basketball star who 'twice set a county record, in 1950 and then he broke it in 1951, a wonderful accomplishment. ${ }^{9}$ But the novel opens with the present tense; Rabbit is trapped in his marriage, an alcoholic pregnant wife in a tiny, shabby apartment with a job as a kitchen-gadget salesman. He suffers from Bovarism phenomenon; his interior life defines him. He feels 'glued in with a lot of busted toys and empty glasses (...) and no way of getting out $^{10}$, to say nothing of his wife 'a floating thing, useless and dangerous to herself as to the others.". No wonder Updike has his protagonist confessing that God would not ask a waterfall to be a tree, meaning of which he cannot help to reconcile the glory of his past with the misery of his present. The sterility of his interior life is matched by imagines of middle-class prosperity and the rise of popular culture. The novel opens with Janice (his wife) blankly watching TV, unable to answer his questions; the house of the Springers is meant to be the product of the economic boom, but it stands out as a parody of middle-class pretentions: "each room seems to contain one more easy chair than is necessary".12 Plunged into the chaos of his life, Rabbit needs order, he demands the beauty beyond cleanness, order and light, even though order comes by trampling on the others. We see him hanging his clothes neatly, in the mess of his house, the continual crisscrossing 
mess -clings to his back like a tightening net. ${ }^{13}$ As soon as he returns home, he opens the closet to take out his hanging coat, and a few chapters later he is looking again for hangers in Ruth's house. Adultery becomes somewhat a spiritual gratification in the postmodern era, to some degrees the expression of sexual freedom women enjoyed in the 1960s. And yet it is a freedom in decomposition. As parents struggle to maintain a resemblance of morality, children are exposed to questionable behaviours (Miriam's conduct at the Club), and America, at first symbol of social mobility, suddenly discovers itself fertile ground for escapism. The novel begins and ends with a flight, but it is the destructiveness of the character's actions to kneel the protagonists down to their doom. A few days after she gave birth, Harry wants Janice to have a drink while he is smoking a cigarette after another. Meanwhile, to fill the hole of his absence she finds some crayons to play with Nelson, not surprisingly she has a breakdown when she fails to stay within the lines in his colouring book. Given this frame, Rabbit's final escape, alike the death of the newborn baby, is all in all the escape from the empty promises of the American Dream. At last, he knows no answers.

Salinger's characters share much with Harry Rabbit Angstrom, not last the repressive McCarthyism and the age of consumerism. In the 1950s economic prosperity became a mass phenomenon: absentminded Janice is watching on TV a children music perform, named Mouseketeers, while Salinger's Glass children are all very precocious, they were regular stars in a radio program called It's a wise child. There is more than a hint from the side of the writers pointing at the contemporary passive reception of entertainment as the reason why the protagonists are all unable to assimilate into society. Rabbit embraces the incapacity to adjust to adult responsibilities: marriage, parenthood, a career, and ultimately, is unable to fulfil any of them. The members of Salinger's Glass family featured in the novel Franny and Zooey are of a similar breed. Fairly impotent to communicate the abyss of their reasoning, Franny and Zooey must decide whether or not to remain actors (famous) or leave the pursuit of fame behind them. Accordingly, they are powerless in the transaction from adolescence to adulthood. In Salinger, more than Updike and Auster the mediocrity of social existence shoulders the mystery of personality. Lane's repressed emotional conflicts are in sharp contrast with Franny's need for affection. He plays out as a symbol of egotism, intellectualism, and academicism. Sophisticated if not uninspired Yale intellectual who eats frog's legs, snails, and octopus, he is too self-absorbed to notice her lack of appetite, or the perspiration of her forehead, clear signs of anxiety. On the other hand, Franny stands out as a talented young actress, disenchanted with the all of contemporaneity, slightly bohemian (she will order a chicken sandwich in a fancy restaurant), at the beginning of a spiritual crisis. None of the Glass siblings seems capable of functioning as adults. Seymour Glass, the invisible eldest brother, is the real ghost haunting the protagonists behind the curtains of the narration. His post-war suicide recalls the post-traumatic disorder of thousands of soldiers returning home, and it would not be too daring to see in his suicide the same fate waiting for the more popular young Holden Caulfield (The Catcher in the Rye). Holden is dismissed from several schools and very much alike Harry Rabbit, his manic quest for companionship flings him from one meaningless encounter to another. Alike Rabbit, he goes through the artifice of being an adult by consuming alcohol in bars, smoking, and soliciting a prostitute for sex while hiding out in New York City. Described with an adult outlook, very tall and already spotting some grey hair, he is far from being emotionally 
equipped to accept the responsibilities of adulthood. However it would be no more than a modern Bildungsroman with adulthood as a battlefield, were not for a sociological perspective that must place Holden and the Glass saga within the perimeters of the American literature in the 1950s. At the dawn of her spiritual awakening, Salinger has Franny admitting being affected by the egomaniac general atmosphere:

I'm sick of not having the courage to be an absolute nobody.

I'm just sick of ego, ego, ego. My own and everybody else's. I'm sick of everybody that wants to get somewhere, do something distinguished and all, be somebody interesting. It's disgusting. ${ }^{14}$

The apparent diversification brought in by the market economy, the heteronomy of pluralised cultural fields, is, in fact, a cultural homogeneity in disguise where individual complexity is overshadowed by the triumph of consumerist standardization. In other words, the logic of advanced capitalist society, framed within the psychological violence of the Cold War, is also the age of conformity, a moment of shallowness and artificiality of modern American culture. Consequently, the celebrity Franny and Zooey so vehemently brushed off is the intellectual awareness over the abuse of Western individualism. Somewhere along the line develops DeLillo's agenda. Compared to the first postmodernist novels, appearing decades after Rabbit Run, and Franny \& Zooey, DeLillo's White Noise introduces a deeper analysis over the role of the media as an enslaving force in society, and the changing structure of the family. The Glass siblings all are former regular guests in a radio program; Rabbit loathes TV and tugs his wife dumb for enjoying it. Following the lead, DeLillo depicts a world where academia is a limbo of cultural relativism and media are the tools through which such a limbo is created. Jack Gladney's lecturing on Hitler pairs with fellow professor
Murray Jay Siskind, who simultaneously lectures on pop culture epitomised by Elvis Presley. The join lecture more than pointing out the fictional similarities between the fascist leader and the pop icon has to be read as Benjamin's alarm on the aestheticisation of reality (Fascism), and politicisation of art (Communism) where art is subordinated to politics and together is a part of it. Back to American postmodernism, the absurdity of the scene represents the last step of the logic of marketisation: the commodification of tragedy for academic consumption. Seemingly DeLillo is proposing that TV and media have so anaesthetised the public's ability to think for themselves that they no longer can differentiate between a man responsible for millions of deaths and a pop singer - they are both simply a moment of entertainment for a desensitised public. Were people this dumb before television? Is the question the practical Vernon, Jack's father in law, asks an abstract character as Jack. The rhetorical conflict is not as comic as it seems, but it reaches a Dedalian complexity, as the critic Irving Howe already noticed in 1959:

There is no longer a society to write about. In former years you knew where you stood: the peasant had the Bible; the maniacs read Mein Kampf. Now people no longer have any opinions; they have refrigerators. Instead of illusions, we have television, instead of tradition, the Volkswagen. The only way to catch the spirit of the times is to write a handbook on home appliances. ${ }^{15}$

From an eagle's view, postmodernism interrupts the last four centuries of domination of an autonomous subject; structure, rules, codes, functions, social phenomena, dominates the scene of contemporaneity. As a visual image, technology is a physical representation. Back to White Noise, shortly after the ATM confirms Jack's own financial calculations, he is altogether filled with a sense of peace. The violence of the narration does not posit on episodes of physical violence, as it does happen in Chinese 
postmodern novels, but in the overall atmosphere of uncertainty into people's existence. The black toxic cloud threatens global extermination and as a preventive act postmodernism creates a hyperreality (Baudrillard, 1981) where the real world is supplanted by its representation. Murray argues that the 'most photographed barn in America' is not intrinsically significant. Rather, the fact that countless tourists have come to visit the location gives the site meaning and value. The SIMUVAC (Simulated Evacuation), people rehearsing apocalyptic scenario, is perhaps the most extreme example of the tension between what is real and what is artificial, but it is Jack's daughter Bee to capture the drama of the Schopenhauerian dialectic between life and representation adjusted to the present age. When coming across passengers that had just avoided a fatal plane crash she admits that 'they went through all that for nothing' just because the media did not record the experience. Life then becomes real only when men become actors.

The disintegration of marriage and the family previously seen in Salinger and Updike comes as a logical consequence with, if possible, more devastating effects. Jack is on his fifth marriage while his actual wife Babette accepts to sleep with a pharmacist-like project manager in exchange for anti-fear-of-death pills. Indeed, the violence of death, factual or representational, is the literary device closing the gap between American and Chinese postmodernism. Jack, wonders between death's expressions: the fear of death (Jack and Babette discussing about death), the representation of it (the black chemical cloud), the simulation of it (the SIMUVAC organization which simulates a post-death scenario), and the vision of it (Jack's attempt of homicide). Life reveals itself as a meaningless experience, the whole world before the end is a meaningless experience and the last moment of man's creation is the dramatic awareness of one own futility:
It is like we've been flung back in time,» he said. «Here we are in the Stone Age, knowing all these great things after centuries of progress but what can we do to make life easier for the Stone Agers? Can we make a refrigerator? Can we even explain how it works? What is electricity? What is light? We experience these things every day of our lives but what good does it do if we find ourselves hurled back in time and we cannot even tell people the basic principles much less actually make something that would improve conditions. Name one thing you could make. ${ }^{16}$

As to be able to reach tomorrow, tragedy switches into black comedy: Jack, professor of Hitler studies who does not speak German, -seemingly a basic skill for the Hitler studies-, Jack rehearsing his attempt of homicide, Jack's youngest son driving a tricycle along the highway. Scepticism leads to a grotesque moment that makes the end bearable; cynicism becomes a space where death cannot be solved, and life cannot be dealt with. At last contaminated sunsets and peaceful supermarkets are the synthetic imagines of late capitalism. Such a metaphor manages to preserve itself within the chaos of the city, and the city is usually New York. The middle class protagonist is the New Yorker, which has very little relation to the city from which it takes its name. Alienated, faceless, nameless people bump into each other, fighting off the uncertainty of the Friday night, the perversity of a cocktail party, the cost of divorces, the color of toxic clouds. New York, the city at large, is the nightmare they all dreamed of. Paul Austen's Moon Palace in spite of the surrealist fantasies the title suggests is less an attempt to sketch an alternative path through imagination as it is a subtle criticism on the American dream a few decades after Salinger and Fitzgerald. The 1893 Columbian Exposition at the Chicago World's Fair and the 1969 Moon Landing stands as some of humanity's greatest accomplishments. But it is through the failure of the characters that Austen outlines personal and social decline. The three generations of male characters, Marco Fogg, Thomas Effing, and Salomon Barber (respectively, 
son, grandfather and father), are for different reasons fatherless, but following the cyclic family pattern they all wander between Central Park and the streets of Manhattan. They are in fact displaced New Yorkers. Abandoned to the chaos of the world, searching for a secret harmony, the disintegration of their personal relationship is more than a hint of the fact that ultimately they did not find it. Marco, alike Holden has a strong contempt for the world: refusing to look things 'squarely in the face', it allows him to indulge in an adolescent state of selfishness. Like Gatsby he bounces back into imagination choosing to face the ideal created for himself rather than the reality of a poor discovery:

No matter how great an artist he might have been, Julian's Barber paintings could never match the ones that Thomas Effing had already given to me (..). I had dreamed them for myself from his words, and as such, they were perfect, infinite, more exact in their representation of the real than reality itself. As long as I did not open my eyes, I could go on imagining them forever. ${ }^{17}$

Paragraph this one that closely recalls Gatsby not wanting to kiss Daisy so he could go on fantasying about her as the mind of God. However, it would be an intellectual mistake to read this narrative as escapist novels; as I said in my introduction postmodernism takes tragedy for granted, postmodern novels move around the rubble of the end of history. Thus, from the side of the writers, prevail the belief of history as a regressive process or that of contemporaneity as the implosion of the project of Enlightenment. As in Benjamin's reading of Klee's Angelus Novus, the storm of progress propels us into the future, but we have turned our back to it. The most inspiringly confirm in this sense is the last sentence in The Great Gatsby:

Tomorrow we will run faster, stretch out our arms farther... and one fine morning- So we beat on, boats against the current, borne back ceaselessly into the past. $^{18}$
In an endless shifting between the anchoring past and the disappearing future, we are like boats that propel themselves forward, while the current pushes us back towards our starting place. Only once Don Juan and Quixote have been cured, transformed into a civil servant, the like of Gatsby dismissed from the stage of literature, the predicaments of postmodernity will take shape. The novels I just mentioned do not deal directly with the postwar American experience but refer to it constantly. Irving Howe, writing on mass society and the emergence of postmodernism in American fiction during the 1950s, well observes that postmodern novels gain from their critique of American life their "true subject: the recurrent search - in America, almost a national obsession for personal identity and freedom". ${ }^{19}$ But he forgot to mention what was found in the ashes of the American Dream. America discovered nihilism at last.

\section{Chinese Postmodern Trauma}

The chronicle of Chinese postmodern literature is to be approached through the trauma of history, more specifically the logic of ideology. In other words, the features of PostMaoist China are to be found within Maoism. Indeed, the legacy of Maoism marks the whole of contemporary Chinese literature with not just a scar, but a ceaseless burning flame. At the death of Mao, Scar Literature had to deal only with the need to describe an individuality damaged by the logic of ideology, but what came after that had to deal with an identity damaged by the horror of the past. More than four decades from its ending, the Great Cultural Revolution still accompanies Chinese writers incapable of distinguishing between trauma and an aborted utopia. Avant-garde artists in the 1980s produced a dramatic break from the conventions of modern Chinese literature, the political emphasis of Scar Literature and the nostalgic approach of Roots- 
seeking writers. A mutiny, as Xiaobin Yang (2002) inspiringly defined, from the literary aim of Chinese modernity, grounded on the vision of the artist as a saviour of the masses, and art as an instrument of moral education. The Avantgardist experimentation is the coming of age of a literature disengaged from the political arena of Maoism, and irreverent to the temporal logic of Deng's China, a pure narrative whose implicit aim is that of deconstructing the mainstream history. It presents itself as a Chinese box in which one story's meaning is within the other, perspective and time sequence do not follow any order, the narrative flows from one temporal dimension to another making difficult for the reader to visualise when or where the events are located. Characters step into each other's fantasies making of the novel a sort of dreamland, in which difficult is to tell whether the events described actually took place or rather are a mere production in the troubled minds of its characters. Can Xue's and Ge Fei's stories, Can Xue more than Ge Fei, are filled with unsettling feelings of uncertainty that spin from estrangement to terror, from expectation to anxiety in response to ordinary events: Yet, not quite magic realism. In Chinese Avant-garde, the magical realism's poetics of enchantment is redressed with a poetics of uncertainty, from the side of the reader because he cannot entirely assimilate the strange event, and from the side of the author because the supernatural is never absorbed into natural. The overall significance can never be fixed into the synthetic stage of the Hegelian narrative, contradictions and doubts remain unsolved within the indeterminacy of a dream. Specifically, this hesitation is suspended in Can Xue because, the coherence of people who fly or turn into animals, unfold according to the logic of dreams thus compelling the reading to be a psychological experience. Precariety and axiety are again to be found in Yu Hua, because of the abnormal violence of the narration, and in
Ge Fei because of a narrative where the enigma is worth more than its solution. The texts, as a result, do not have a magical realist approach, or magic elements, substituted in some cases by a mysterious atmosphere and more often by a frightening fantastic whose images are fully charged with allegorical significance. My lead is that Chinese 'magic' enlarges into fantastic, a violent fantastic, as a consequence of the history of China. The traces of Maoist discourse still lay behind the line of consciousness as an unresolved traumatic memory, and I cannot but deeply agree with the clear statement of Xiaobin Yang:

Chinese Avant-garde fiction is a profound textual adventure that re-experiences the inextricable relationship between the hideous atrocities of the past and the captivating discourse that justifies historical violence and invalidates the comprehensibility of the whole situation..$^{20}$

The logic behind the narrative of violence, the dissolution of the rational subject in contemporary Chinese fiction is altogether the representation of the irrational the Cultural Revolution was the bearer of, whose violence was inflicted in the name of the proletarian revolution. Simultaneously, the inadequacy of the subject before a linear explanation plays out in the Avant-garde as an Oedipal assassination where the father, -Maoism, the rhetoric of the national discourse and so on-, is murdered through the allegorical alternative. Unlike American postmodernism, Chinese Avant-garde does not depict an alternative reality but the impossibility of it, though for both of them a layer of nihilism is the ultimate doom. Realist conventions are shattered, there is no plot construction, no clear setting, symbology cannot be decoded, the narration shifts to and fro from the first to the third person narrator producing dizziness in the reader. Simultaneously, the dreamscape of the narration concurs to forge surrealism, but it does not help in the construction of self, it naturally 
dismembers it. If the reader has some difficulties on sympathising with the protagonists that is because there is no such as a protagonist, Avantgardist characters do not go anywhere; they drift apart submitting to the killing fields of their psyche. Flock of Brown Birds might as well be considered the key work of Chinese experimental fiction, a dream of circular logic, much like $\mathrm{Yu}$ Hua's This Story is for Willow, where the beauty of the prose compensates for the lack of a solid plot. It still moves between the boundaries of realism, but the attempts to undo the convention of realism are omnipresent. The protagonist is a writer, allegedly Ge Fei himself, who retreats to the solitude of Waterside -the publisher's resortto finish his novel. Seasons would not change if it were not for the brown migratory brown birds crossing the sky and interfering with the stillness of his time. And for some reasons not quite clear to the writer either, he knows that if the flock were to vanish, they would take time with them. One day the peace of Waterside, where he seems to be the only inhabitant, is broken by the appearance of a mysterious woman dressed in orange-red. She carries a large folder, perhaps an art portfolio or a mirror. A portfolio indeed. Qi, her name (Chinese homophone of wife), and she presumes to know him though he has no recollection of her. They sit facing each other all night long, nothing really happens, a cup of coffee is drunken, a story unfolded. Time passed. In his emotional retrospect, the sudden death of his wife on their wedding day seems to suggest that time was never enough and as the story ends Qi takes her leave. Again, it seems too soon. Several seasons later she eventually comes back, but she is just a passerby. Qi claims not to know him as he did at the beginning of the novel. She might not be Qi, after all, perhaps an illusion, the ghost of his former wife, perhaps, as the narrator years before, she is Qi, though she does not remember it. The story has gone full circle, but it is just misrecognition: in Avantgarde fiction, circularity is broken implying history's lack unity. The ending scene is identical to the opening one, she is wearing an orange-red dress, she carries in her arms the same canvas portfolio folder, but when she unties the light green strap, the boundless void of the narration is served again: it is a tiny mirror indeed. While a story blends into another, and the characters struggle to recognise themselves, reality does not collapse, but time does, distorted, disconnected, confused, eventually forgotten. Memory, at last, is unreliable and so is the author's capacity to find sense in the world.

Can Xue places her work within a form of writing that I have already excluded from the category of magic realism where otherwise the plot is well defined, neither does she rely on a recognisable version of reality to support her magical aspect. The narration is structured around an inner logic. Her narrative rises from the unpredictable encounter of disparate objects and events, of two realities that by all appearances have nothing to link them. Consequently, being subject and object so far apart from each other, reason fails to connect them. Exemplification is the well-known short story The Hut on the Mountain, quintessential of Can Xue's writing. The unreasonable suffering is not given by a specific happening, but by the menacing atmosphere oppressing the whole. Violence here, unlike other works, is psychological, the reader is left with the awkward feeling that something has been violated, the narrator's intimacy, perhaps her virginity, childhood, past. She sees countless tiny holes poked by fingers in the window screens, the wolves poke their heads in through the cracks in the door, her desk drawers have been searched, and now something is missing. The word 'swollen' appears three times: twice referring to the narrating I 'my swollen head on the pillow', 'the spot would become numb and 
swollen whenever she did that', and once referring to her mother being beaten by a bug hidden in her shoes 'her whole leg was swollen like a thick lead pipe'. It might not have a political implication, but it evokes traumatic effect of physical suffering. Compulsive characters act within the space of a few pages without a sequitur. Fear is a general threat, Sartre's aphorism the hell is the other finds here a natural dimension. The mother is tortured by the sound of the opening drawers: 'she was so tortured by the sound that every time she heard it, she'd soak her head in cold water until she caught a bad cold', ${ }^{21}$ the father has been haunted for twenty years by a pair of scissors dropped at the bottom of the well. Matters of fact, no scissors have ever fallen into the well. The protagonist 'I' is obsessed with her drawers, -opening and shutting them closed becomes a ring on the chain of madness rather than a daily routine-, and by the others. She is hypersensitive to sounds; she is kept awake by the thieves wandering at night, the man in the hut banging against the door, big rats running in the wind, rocks rolling down the mountain, her father howling. Nevertheless, as the source of disturbance is undiscovered, we might deduce as well that dangers and threats are products of the narrator's hallucinated imagination. 'Everything has its own cause from way back. Everything'22 is the allegorical statement embodying the meaning of the story if a meaning there is at all. The hallucinating sequence of events, -the man locked up in the hut, the father turning into a wolf at night, the invasion of bugs at daybreak- is a clear recall of Kafka's metamorphosis, but it is the possibility of violence lingering within the narration, -the mother thinking of breaking the 'I' narrator's arms, the father thinking of committing suicide-, to call out the universe of symbolism.

However, while in Ge Fei and Can Xue violence tends to be psychological, an inner repressed status, in Yu Hua it becomes physical.
Yu Hua's texts, more than Can Xue's and Ge Fei 's, are obviously connected to the political, focus is on the body scheduled for physical destruction, and the body acting as a metaphor for the cultural nihilism China went through in the Maoist age. In $1986 \mathrm{Yu}$ Hua sets his short story in a postmodern or post-revolutionary landscape, the welfare produced by the economic reforms plunged China into blissful historical amnesia: the walls have been painted over, a minivan advertises contraception. The surface of the revolution has been whitewashed, but the efforts are to no avail, the past is the present. A school history teacher, who had disappeared during the political upheaval leaving behind his wife and a three years old daughter, reappears some twelve years later as a madman in the street of a peaceful town sawing his own body. The nameless protagonist is the Avant-gardist's answer to Zijun in Chen Guokai's What should I do. In this 'scar-story', written at the end of the $70 \mathrm{~s}$, the protagonist's husband comes back home eight years later wearing on his face the scars of the Cultural Revolution-His face was covered with terrifying scars, and his upper lip was horribly split. ${ }^{23}$ The story of a broken family spins around the main happenings of the socialist tragedy, political struggle, persecution, proletarian dictatorship. What should I do? is the piece last stirring line. But in the 90s the dramatic implications of the Cultural Revolution are on the table, the revolution has been re-elaborated, condemned, understood in its epilogue. Ge Fei in the Taiwanese edition of his first novel, The Enemy, paramountly condenses everyone's thought by confessing that he is 'shrouded by a shadow from long ago, which spanned my all childhood and left indelible traces in my memory'. The trauma of the revolution establishes a logic of madness over the logic of memory, no reconciliation between characters and events, subject and object, history and reason is ever possible. Hence, in Yu Hua, the wounds inflicted by decades of political hysteria, 
assume the shape of distorted pictures and grotesque complexions. The teacher going back home after years of hardship strikes as a good giant crossing an old town ready for the spring festival, his broken feet unusually large so that they rang out at each step. But for the good giant, there is no adjustment, individual or domestic, as it happens in many of wound-retrospect literature. The self-mutilation, the dismembering of the body (nose-cutting, leg chopping and so on) corresponds to the impossibility of going back home for those who outlived the political persecution of recent history. There is nothing left to do, is the answer Yu Hua offers to the initial scar-question. Truth makes people free and mortal. The veil of Maoism is finally ripped open, to reveal that the logic behind the master discourse, opportune to justify the political persecution, was not based on rationality, but on its deformation as the violence of the mutilation attests. The nauseating details of the scenes, the graphic accounts of the severing of the body, the horrifying tortures lasting pages of descriptions subverts the linearity of realism; there are no heroes, time is smashed, space deconstructed. The cruelty of death denies rationality tout court, hope is wholehearted vanished, and in the sequel, life cannot be comprehended. The conclusion is the same desolating acceptance already seen in Fitzgerald and DeLillo, though Chinese Avantgarde adds to it a nightmarish atmosphere, a display of human catastrophe that incapacitates any coherent representation.

As a reaction to the Avant-gardist experimentation, the shaking structure of the text and the destructiveness of the content, the second half of the $90 \mathrm{~s}$ opens to a postsocialist realist school or new-state of affair ${ }^{24}$ literature, a production somewhere between the stillness of traditional realism and the extreme subjectivity of high modernism. In contrast, to the aesthetic of socialist realism, the ideological truth is stripped away from the text. Loyal to the path spotted by the Avant-garde, this is a literature that cut off the grand narration, national allegory, the rhetoric of writing serving the people, but it is staged on individual's impression and experience. The reality writers draw up their ideas from is shaking, it is a platform in progress, uncertainty and disorientation overshadows the daily routine, man is left alone to face a common fate. This is the narrative of the last Yu Hua and Su Tong to name some, a political fable with realistic mode registering the movements outside as crucial elements of human experience. Narrative captures the transient through the eyes of the witnesses flashing upon the eyes the images of what they just saw. The tragedy of Chinese history borders the happenings of the protagonists' broken life, the tone of the narration alternates between the indifference of history and subjective elements of compassion. Indeed similar to historical fiction, but different because here history is reinvented, de-sacralized in a promiscuous construct that is together, profound and superficial, tragic and absurd, historical and fictional. How can they manage such equilibrium? Through the ambiguity of a mise en abyme, a technical spell, a part of the process of deconstruction, the realist hole that tosses down tragedy to the extent that we do not quite know whether the characters are acting or living, playing a scene within the scene (fiction within the fiction) or according to the script. Baldy Li, the metteur en scene, in Yu Hua's Brothers, acts throughout the novel out of excess, incongruity or contrast to the object, the outcome is a displacement out of the linearity of the plot. When in chapter thirty-eight, for instance, he single-handedly resigned from the factory he so well managed, the absurdity of the scene creates a comical effect:

He proceeded to deliver an hour-long impassioned speech in which he spent fifty- nine minutes praising his own achievements and the final minute 
reapproving the two cripples as factory's director and deputy director. He concluded by sadly declaring that they, the Good Works Factory's workers, had unanimously accepted Director Baldy Li's letter of resignation. Baldy Li tearfully concluded, "Thank you." 25

The objective correlative is imperfect, the emotional algebra between the outside object and the inner feelings does not combine, facts exceed emotions, and more often than not, do not quite match. Drama, collective and individual, covers the whole plot, we are offered a detailed description of tortures inflicted by the madness of the Cultural Revolution, we record the broken lives of those who survived, and we are given an insight of the destructive consequences of economic developments. But it is not tragedy yet; there are fundamental conceptual elements missing. There is no catharsis for the protagonists; they are not allowed to receive final purification, even if at some stage of the narration their fate seems taking a positive turn, in the end, they always lose. Su Tong's Madwoman is taken away to a sanatorium, Fugui and Dongliang are left alone with a pile of memories and mistakes to decode, Sun Guanglin kneels down at the side of life, Lin Hongs -whose natural beauty motivates her innocence-, ends up opening a bordello, Song Gangs -the pure face of time- is ultimately a victim of the market economy and his weaknesses. ${ }^{26}$ This is realism without salvation, a crude ostentation of desolation standing as one of the main traits of Chinese postmodern literature. There is not inevitability (ekkyklema), a reverse of fortune, an incident which gives start to a cause-effect plot, and there is not the intervention of a Deus ex machina, (usually a divinity in the Greek tragedy), a plot device to appeal when all else fails, coming from nowhere to untangle the dramatic course of events. Tragedy, classic or modern, is based on an accidental element, an absolutely unforeseeable circumstance, a twist of fate, an inevitable, unavoidable twist of fate that changes the course of the plot dramatically. The tragedy is destiny happening, for this reason, it generates empathy and fear, for it is unexpected. But most of these realist works are placed on a post-Euripides stage where tragedy is explained, focusing on the dialogue at the expense of the pathos behind it, somewhat turning the inevitability into rationality. In Brothers, at the very beginning, the first paragraph of chapter one, we are told that Baldy Li used to have a brother who died three years earlier, but the story of Baldy Li's brother, Song Gang, will accompany us until the very closing of the novel. In chapter thirtyseven we are told that the heartbroken Baldy $\mathrm{Li}$, a decade later, will single-handedly account for the GDP of the entire county. In Wang Anyi's most dramatic work, The Song of Everlasting Sorrow, the reader's suspense is again cut short by sudden revelations. The chapter titled 'Miss Third Place', to name one, reveals beforehand the final result of Miss Shanghai. Or we curiously follow the slow unfolding of Wang Qiyao's romance when abruptly we find the lovers holding after sexual intercourse. We are shown the end at the start; we are deprived of curiosity and inquietude, pathos, (the aim of the tragedy) is removed from the waiting, the narration is always aborted before it reaches its height. Yu Hua and per extension this trend of realism, does not allow the tragedy to explode in its complexity, and it is not so much for the purpose of a comic interlude. Clearly, it is necessary to avoid instigating a sensitive topic they tacitly agreed not to and being forced to dig up answers already consigned to the official history. Thus, they furtively break the crescendo by adding an amusing device. In Brothers the atrocious sounds of people being tortured coming from the warehouse and Song Fangping emaciated face are softened by the wonder of the two brothers for the arm-dangling march. Again the reader cannot but smile when, soon after having found out of Song Gang's suicide, 
Baldy Li and Lin Hong curse at each other as it was a cursing competition. If the first Avantgarde experimentation resolved evil with silence, here the narrator forces the reader to laugh on the ashes of the evil. Is it enough to call it redemption? $\mathrm{Xu}$ Sanguan, the metteur en scene in Yu Hua's Chronicle of a Blood Merchant, is told by a stranger (the audience) to denounce Xu Yulan, his wife, at home. A struggle session, therefore, has to take place within domestic walls. $\mathrm{Xu}$ Sanguan set forward to organise the guidelines in order to give credibility to the struggle session and make it seem as real as possible: the whole family occupies a preordered position, the three sons in a row, $\mathrm{Xu}$ Sanguan in front of them, $\mathrm{Xu}$ Yulan standing on a side. Afterwards, they are told how to proceed as according to an invisible script save interrupting the session when it takes an unforeseeable turn. As the characters are all acting out of commands the effect produced is similar to a theatrical sequence:

You're not allowed to call her Mom at the struggle session. You cannot call her mom until we're finished with the meeting. ${ }^{27}$

Lawrence's dualism between life values and the mechanisation of human nature reviews here a new dynamic with the difference that the role occupied by the Western system machine is replaced by the excess of the Party system. None of the protagonists is a tragic hero, detached from the historical present, rather shallow in their answers, similar to a Kafkaesque narration they are absurd characters plunged into the absurdity of history. Alike in Kafka o Beckett, we are not reading tragedy anymore, but the comedy of the absurd, the ability to provoke a laugh from the horror. At odds with the female writing in the 1990 s, the male narrative reserves no space to the emotional seizure on the part of the subject; it is not so much about the idea of death and the tale of nostalgia over a mythical past, as it is an accurate lack of introspection from the author and the characters. As it appears, postsocialist anomie is one of the hidden traits of post-Mao China, on the other hand, being emotionally uninvolved allows them to survive.

A clear divorce from the Avant-garde engagement and with no commitment to the loyalty of realism, new historical fiction ${ }^{28}$ in the Post-New Era production generally supports the journey of a family saga spanning from one generation to another, experiencing a lapse of time roughly stretching from the pre-Republican era up to the age of capitalism. As it mostly takes place in the countryside, it is not unfair to look at it as an extension of that aestheticisation of the past that roots-seeking writers mastered so well. At the same time, the impressive expansion of the market and the massive migration to the city, in short, the construction of modernity, forced the authors to demonstrate that those roots are imaginary. Mo Yan's Northeast Gaomi Township and Su Tong's Maple Village whether they are real or not is not much the issue here, they stand as a whimpering mirror, at times as a yearning call against the violence and decay of the present, at times as a setting of disease and corruption. History not necessarily is based on objective facts, and it is always accompanied by a subjective imaginary which weakens the reliability of the structure. So it happens that in Su Tong's My Life as Emperor and Binu and the Great Wall of China, space and time are not specified. It is because history is still not the primary concern of contemporary writers, but a mere setting. The absence of historical personages and more over the addition of mythical-magical elements suggest that the epic discourse converges into lyricism and a reflection of decadence. My Life as Emperor is set under the fictive Xie dynastic empire, torture and conspiracy frame the brief reign of the young emperor and the empire itself slowly crumbles down because of an inescapable plague resting within any human embracement. 
In Yu Hua's To Live the protagonist Fu Gui goes through the entirety of the Chinese Socialist Revolution sensing the immaturity of history. In times of land reform, Yu Hua has the villagers smashing their cooking pots to follow the way towards communism and a few pages later, at the begging of the famine, he has the team leader urging everyone to buy new pots as the common dining hall is going to shut. The episode should be read in connection with the attack Deng Xiaoping will move some decades later to the 'iron rice bowl' traditional symbol of permanent employment which became in the 90 s impediment to the market reforms. It is the collapse of the revolution; the socialist utopia did not live up its expectation, decadence is therefore what is left of decades of propaganda and together the loss of belief in what history will bring. Mo Yan's The Red Sorghum links together the glorious past of the ancestors with the degeneration of the present, but the real protagonist is war itself, and it is war to be immoral. Examples of historical fiction, these texts narrate the rise and fall of patriarchal families, days of sickness and death, plagues and epidemics, marking the fatality of their decline with no redemption. The tendency to overlook historical events and personages represent, from the side of the authors, the judgment against the official historiography and together with an admission of history's vicious nature. The collective converges into personal experience; history is subjectivised, retailored by the writer own perception, his recognition, his memories, the past echoes violence and the present is either ruin or yet to be located. The dialogue between different momentum does not lie in the objective reality. Instead, it is a sense of fatalism rejecting all along the project of modernity. In Su Tong's historical fiction the soul of history is eaten away by the plague of time, and the protagonists are ferocious, immoral, infected by evil, yet the reader cannot but sympathise with them. Five
Dragons in Rice before being a murderer is a victim of people's hatred, of physical and spiritual violence perpetrated by indifferent hands. Nineteen Thirty-four Escapes builds up a projection over the fate of human life. The visual images of dissipation are given by the immense figure of Grandmother Jiang abandoned by her husband, an object of sexual desired, raped, abandoned again. She is the anti-hero parexcellence, ferocious in her revenge, guilty of infanticide and murder, tame-less before the plague, the poverty, the pool of corpses piling in front of her door every day. After having already buried five of her children, out of an act of revenge, she is taken away by the lover of her husband even the last infant one. She reached for them, but it is already too late, they are beyond the Yangtze River, the line of demarcation between countryside and city, allegorical transfer from the poverty of the traditional countryside to the success of the modern city. She cannot cross over. But the death of the oldest son, Dingo, who had moved to the city to become a bamboo craftsman like his father, reminds us that there is no real escape. No matter where history is rotten and doomed are the protagonists. In Opium Family genetic deficiency is at stake, but it is the all scaffolding of human performances to crumble down. Most evident is the erosion of the genetic foundation: four of Liu Laoxia's children are deformed and placed in the river to float downstream, the fifth one is an idiot and the only healthy one, Liu Chencao, is illegitimate. That goes together with the moral collapse of the fathers: the family patriarch who sells his daughter to an old bandit, for her to be later raped by a peasant who becomes a communist leader, illustrates the writer's dissatisfaction with the present state. As the novel enters the phase of the Communist revolution, the protagonists of the Republican era are erased from the surface of history by the consequences of the land reform. 
Again is a final, spectacular fire to seal the tragic destiny of those coping with darkness. History at this stage lacks of utopian enthusiasm, the boundaries between past and present, dead and living, good and bad, are dropped, man is fooled and history, emptied of ideological content, becomes irrational. What is more striking is that there is no straightforward relationship between the actors and their search for meanings, the outcome of the dialectic between signified and signifier is independent of each other. The legendary Commander Yu in the Red Sorghum, betrayed by his compatriots, keeps fighting alone the Japanese to defend a deserted land just to wound up in exile in a foreign country. The good giant Song Fanping in Brothers writes the last love letter just before his body is mercilessly smashed, Dongliang's father in The Boat to Redemption, will drown himself to death under the shame of a political misunderstanding. For those who survived the past, history seems to be a cruel labyrinth of significance with no escape to rationality. From year to year, from generation to generation, it is a merciless fate rather than reason, what shapes people's destiny which is a story of decline: health, family, morality, beauty, we do not see them accomplishing, we are shown how they decay. My Life as Emperor could be read as the mystical tale of a cruel emperor turning into a tight-rope walker and Buddhist adept. But we would misjudge the tale. The final slaughtering and the burning of the imperial Great Xie Palace have to be placed within a larger discourse over humanity's condition: the death of the innocent eight-year-old Jade Locket, more than that of the last emperor Duanwen, robbed men of any possible future. The pile of rubble of what was once the splendor of halls and gardens may be priceless may be worthless, confesses the former emperor, they do not just declare the biological shift of power, but the mischievous forces of history undermining free will. To burn, hence, is not the palace itself, but the vanity of the historical process. History is irrational then, otherwise it is left un-decoded. Often told through the eyes of a child, Bald Li and Song Gang in Yu Hua's Brothers, Sun Gunglin in Cries in the Drizzle, Dongliang in Su Tong's The Boat to Redemption, they go through their childhood during the years of the Cultural Revolution: parade, big poster, paper dunce cups, wooden placards, armbands, giggle before their eyes like carnivalesque storm of their youth. To their eyes, one of the most dramatic events in words history becomes a feast they want to participate in. And when it comes to adults, maturity appears to be nothing, a void between a miserable youth and a childish old age. Defenseless, they submit to history without really understanding why the world has turned upside down.

\section{The Dehumanization of Post-modernity}

Postmodern writers seem well aware of a gap of guilt between history and humanity. Thinking of America in the decade's post World War II and it is evident how important literature became a rejection of America itself. So was for China. With regard to the text, postmodern fiction produced an epistemic break from the grand narrative of modernism embracing a technical and ontological scepticism. Historical metafiction, events and people fictionalised, temporal distortion, a pastiche of genres and styles, distinguish the peculiarity of the postmodern perspective, where the Barthesian's death of the author performs as a technical device that prevents the author from dictating his meaning. Narrative and cultural life, intersecting each other, are viewed as a moment of a text producing new text and new culture, but more often than not the outcome is a cultural hybrid: aesthetic wants to be ethnic, religion is stained by fanaticism, and fiction is invaded by reality. Fiction becomes a 
collage, a montage of happenings where the daily dynamic between social actors turns into the dialectic between producer and consumer. The exuberance of the former and the needs of the latter contribute to the creation: bodies mutilated, dead children at the corner shop, a bed shaken after an orgasm, images of our contemporaneity dissipates every distance between art, life, moral, and pleasure. As a reaction to the madness of the Twentieth-century ideologies, postmodernism is the end of things, the end of art (Duchamp), the end of the author (Barthes), the end of history (Fukuyama), the death of man (Foucault). Prophetic diagnoses have been realised, moving forward is to turn systematically towards the past. A deeper analysis, which is not the focus of this paper, would bring us to the minimalism of the text. Salinger's protagonists, Updike's, Austen`s, all suffer from paranoia, the antagonism between the outside and their stasis reflects the idea of a modern society as chaotic and intimidating. But besides a few cases, we struggle to remember the names of the characters. Literature acquires sociological strength by making everyday people protagonist of a daily story without giving them any leading task, not anymore Anna Karenina and Raskolnikov, but professions and places. By the end of the novel, we have a better understanding of where lovers and criminals come from, but at the same time literature loses its poetry and somewhat its magic, aesthetic is no longer the sanctuary of production, it becomes confusing, at times dull for all those who are neither lovers nor criminals. The erosion of invisible boundaries between high culture and popular culture is as well the erosion between reality and art. What Josefina Ludmer defined as 'post-autonomy literature', is a space where the dialectic grip reality-fiction comes loose, where different province of significance (art, literature, reality, fiction, politics) lose their specificity altogether and somewhat their own space of autonomy.
Modernist metaphysical fragmentation becomes now a postmodern dissolution of the plot, language, sentence structure, character, theme, and setting. All considered it is a rejection of America, I said above. Salinger rejects the phoniness of a conservative society, an idea under which lurks, injustice, snobbery, moral obscenities. Fitzgerald rather than celebrating the Jazz Age depicts the details of a society incapable of fulfilling its potential, not so much a land of meritocracy after all. That is the incontrovertible meaning of Nick's final judgment 'It was all very careless and confused. They were careless people, Tom and Daisy - they smashed up things and creatures and then retreated back into their money or their vast carelessness, or whatever it was that kept them together, and let other people clean up the mess they had made". ${ }^{29}$ The corruption of the American idealism, tout court the American Dream, reaches its artificial zenith in DeLillo where the run for materialism becomes an abuse of technology, a discrepancy between intellectual development and its achievements. That is because American society changes faster than the ability of the writers to record those changes. On the contrary, Chinese artists, to a larger extent Chinese culture, seem to alter more rapidly than society. And that is the first moment of Chinese postmodernism, better said, Chinese postmodernism starts with a piercing historical awareness, that life disintegrates, and human beings lose their freedom once they are about to grasp it.

For those who came of age in the $60 \mathrm{~s}$, Maoism was a cataclysm, and the waves travel along the bones of contemporaneity. One of the great work of the reform era, Xu Bing's conceptual art and his massive installation a Book from the Sky (19871991), well symbolises the general atmosphere. He spent three years carving four thousand Chinese characters, printed them in Chinese paper, four volumes, one hundred twenty-six copies, 
bounded them in the format of a classical text from the Song and Ming dynasty. Not an exercise of calligraphy, but a deconstruction of meaning. To a closer look for those familiar with Chinese characters the stunning surprise to realise that none of them exists. The iconoclastic expression has the clear aim to dismantle a thousand years of tradition assuming the futility of human endeavour. Postmodernism is at any latitude a process of deconstruction, in the case of China, history is the structure to be dismounted to be questioned and accepted. Were the Red Guards victims or victimisers? Was the Rustication Movement a waste of youth or idealism? Why the Cultural Revolution? History is dismounted, derided, reduced to madness, ignored, what is left is man. My impression is that contemporary writers, for a postmodernist purpose -which is the deconstruction of Maoist discourse-, use the ghosts of the past, to provoke the collapse of the borderlines between fiction and reality. Inherent the narrative is chaos and chaos helps them to open a crack in the wall of ideology, to disintegrate the totalizing experience of the communist rhetoric grounded on the eloquence of national salvation, the secular collective consciousness. Here, is where the process of deconstruction starts, questioning the nature of history and calling realism into question. And when history was no longer self-sufficient, history began to collapse image by image, piece by piece, bit by bit, emphasising, framing, caricaturizing, the revolution in the attempt to bring to a halt the aesthetic of sublime circling Maoist heritage. In this sense, Chinese postmodernity shares the same features of disintegration, de-collectivisation, depersonalisation as the Western counterpart. They meet on a vanishing land of self-annihilation, where drugs, violence, sexual relation, insanity, death are not a moment of the plot, but a new fiction. The process of deconstruction has reached the last step, from history to the individual, from the individual to the inner-self, the outward silence is balanced by inward voices, an orchestra of fragmented monologues, shy consciousness, a solo of loneliness. Speechless protagonists cut themselves off from the masses, sustained only by the puzzling and introspection phase of their Bildungsroman, whereas the mediocrity of reality is either charmed by the beauty of the imaginary or ignored out of fear.

Memories bring decadence. The Avantgarde experiment turns into violence the scars of the Cultural Revolution, the lighter historical fiction is based on the ruin of history and the deception of the present time, realism in both attempt, male and female, offers images of desolation and abandonment. Starting from Scar Literature crossing the last four decades of Chinese production right down to the Private Female writing, the reader, like the actor, is muted by the bitter-sweet symphony of singularuniversal fate. The drama of human condition is what emerges, at last, alike in Malraux's novel, the need to be intoxicated by an idea, in the case of China that of national salvation, class struggle, in a word communism. In the end, it is the desperate clash between the lightness of an ideal and the impossible weight of a historic betrayal. As it appears, nostalgia, not quite present in American novels, trespasses its temporal dimension to monopolise the plot as a psychological bridge between socialist and post-socialist identity. That because it was much more American than European to believe in the present rather than in the past (American Dream), and it is much more Chinese than American to believe in the future rather than in the present (Great Leap Forward). As part of a Post-ideology discourse, literature evolves towards an autonomous area where taboos are broken but do not disappear, history disengaged and yet revisited over and over again. One cannot resist the temptation to speculate on the political implication of the 
fiction: the savage imaginary, the madness of many of the protagonists, their actions shifting between paranoia and schizophrenia, indicates the violence of personal and collective history, and from the side of the authors their incapacity to redeem it through rationality. Once the text is released from the determinism of ideology the boundaries between real and unreal come loose, it is the disintegration of the past as China knew it. This being the case, it would be nonetheless misleading to read these novels just as a political allegory. Chinese postmodern fiction does not focus on Socialist China, or on the logic of marketisation: it is the clash between the two ideologies what holds the key to a narrative otherwise innocent. Given this desolating scenery, it seems to me evident that if American and Chinese Postmodernism share a common ground, and they do, that would not be economic leadership, but the notion of a national failure, a sense of defeat, setting the tone of the 'post-everything age'. In the wake of World War II, the bombing, the Holocaust, the annihilation of human rights, the beginning of the Cold War, there is no way back to Tolstoy and Dostoyevsky. The Russian writer Evgeny Zamyatin put it very well: Euclid's world is very simple, and Einstein world is very difficult; nevertheless, it is now impossible to return to Euclid's. ${ }^{30}$ To the survivor of the American Dream and the Maoist age, contemporaneity is a riddle whose silence expresses the futility of human desire. At different degrees, the world has become a labyrinth of horrors, haunted by a persecution complex, humanity seems to be a definition between humans and monsters, and because fear indeed acts as narrative space turning life into dust, even the consciousness of the protagonists plays out as a superfluous judgment. Fantastic, mystery, and perhaps love perform as a strategic tool aiming to deconstruct official versions of understanding, on the other hand, they create a space outside the totality of real where the unspeakable can be expressed, at last. But what everyone will be like after having lived through contemporaneity, that is yet to be deciphered.

\footnotetext{
1 Regarding Western Postmodernism, scholarships are virtually endless. To begin with see: Fredric, Jameson (1991). Postmodernism or the Logic of Late Capitalism. London: Verso. Fredric, Jameson (1998). The Cultural Turn. London: Verso. Jean-Francois, Lyotard (1979). La Condition postmoderne. Paris: Editions de Minuit. David, Harvey (1990). The Condition of Postmodernity. Oxford: Blackwell Publishers.

2 Regarding the beginning of Chinese literary postmodernism (后「代), scholarships are endless and very much controversial. For details see: Ning, Wang (1997). «The Mapping of Chinese Postmodernity.» Boundary 2 24, no. 3: 19-40. DOI:10.2307/303705. Postmodernism and China (2000). Edited by Arif Dirlik and Xudong Zhang. Durham and London: Duke University Press. Xiaobin, Yang (2002). The Chinese Postmodern: Trauma and Irony in Chinese Avant-Garde Fiction. Ann Arbor: University of Michigan Press. Xiaobing Tang (1991). 'The function of New Theory: What Does It Mean to Talk About Post-Modernism in China?' Public Culture 4, no. 1, 89-108. Yiwu, Zhang and Michael Berry (1997). «Postmodernism and Chinese Novels of the Nineties.» Boundary 2 24, no. 3: 247-59. DOI:10.2307/303715.

Xiaobin Yang (2002). P. 230.

Paul Pickowicz and Yingjin Zhang (2006). P. 17.

Barrett, William (1969). American Fiction and American values in The American Novel since World War II, 65.

Fitzgerald (2001). P. 115.

Ibid. P. 61.

Ibid. P. 115.

Updike (1993). P. 53

Ibid. (1993). P. 100.

Ibid. (1993). P. 140

Ibid. (1993). P. 150

Ibid. (1993). P. 19.

Salinger (1961). P. 30.

Quoted in Irving Howe (1969). Mass Society and Post-Modern Fiction, in Marcus Kein, 133.

DeLillo (1985). P. 142.

Auster (1989). P. 232.

Fitzgerald (2001). P. 115

Quoted in Irving Howe (1969). Mass Society and Post-Modern Fiction, in Marcus Kein. P. 137.
} 
$20 \quad$ Xiaobin Yang (2002). P. 50.

$21 \quad$ In Jing Wang (1998). P. 215.

22 Ibid. P. 215.

23 Chen, Guokai (1983). What Should I do in Stubborn weeds. Edited by Perry Link. Bloomington: Indiana University Press. P. 94.

24 新状态 (Xin Zhuangtai). Wang Ning in his essay ‘The Mapping of Chinese Modernity’ labeled the new literary tendency as new fiction of stance distinguished from new realist school; Zhang Yiwu in 'Postmodernism and Chinese Novels in the Nineties' refers to new state of affairs; Wendy Larson in 'Woman and the Discourse of Desire in Post- revolutionary China' bargains for situational fiction. To avoid intellectual jargons, here I simply stand for a realist approach.

25 Yu Hua (2009). Chapter 38.

26 In order: Yu Hua (To Live), Su Tong, (The Boat to Redemption), Yu Hua (Cries in the Drizzle), Yu Hua (Brothers), Yu Hua (Brothers).

27 Yu Hua (2004). P. 174.

28 See: Lin, Qingxin (2005). Brushing History Against the Grain. Reading the Chinese Historical Fiction (1986-1999). Hong Kong: Hong Kong University Press.

29 Fitzgerald (1993). P. 114.

30 See John Barth. Available at: http://getpdfree.ga/18682-download-pdf-ebook-torrent-the-literature-of-exhaustion-andthe-literature-of.html

\section{References}

American Post-Modernist Novels (2013). Ipswich, Massachusetts: Salem Press.

Auster, Paul (1989). Moon Palace. New York: Faber and Faber.

China Avant-Garde Fiction (1998). Edited by Jing Wang. Durham \& London: Duke University Press.

Fitzgerard, F. Scott (2001). The Great Gatsby. London: Wordsworth Classics.

Jameson, Fredric (1991). Postmodernism or the Logic of Late Capitalism. London: Verso.

Jiwei, Ci (1994). Dialectic of the Chinese Revolution: From Utopianism to Hedonism. Stanford, Calif.: Stanford University Press.

Updike, John (1993). Rabbit Run. New York: Fawcett Crest.

Pickowicz, Paul (1994). New Chinese Cinemas: Forms, Identities, Politics. Cambridge: Cambridge University Press.

Pickowicz, Paul G and Yingjin Zhang (2006). From Underground to Independence. Alternative Film Culture in Contemporary China. Lanham/Maryland: Rowman \& Littlefield Publ.

Salinger, J.D. (1961). Franny and Zoeey. Boston: Little, Brown, and Company.

Salinger, J.D. (1951). The Catcher in the Rye. Boston: Little, Brown, and Company.

Stubborn Weeds: Popular and Controversial Chinese Literature after the Cultural Revolution (1983). Edited by Perry Link. Bloomington: Indiana University Press.

The American Novel Since World War II (1969). Edited by Marcus Klein. New York: Fawcett Publication.

Yang, Xiaobin. The Chinese Postmodern. Trauma and Irony in Chinese Avant-Garde Fiction (2002). Ann Arbor: The University of Michigan Press.

Yu, Hua (2009). Brothers. New York: Pantheon Books.

Yu, Hua (2004). Chronicle of a Blood Merchant. New York: Anchor Books.

Zhang, Xudong (1997). Chinese Modernism in the Era of Reform. London: Duke University Press.

Zhang, Xudong (2008). The Cultural Politics of Postsocialism. Durham: Duke University Press. 


\section{Американская и китайская литература. \\ Что скрывается под маской постмодернизма: \\ национальная неудача}

\section{А. Кастелли \\ Университет Хайнаня \\ Kumaŭ}

Статья в большей степени представляет собой признание того, что постмодернистская художественная литература являет собой национальную неудачу, и в меньшей степени - сравнительное исследование американской и китайской постмодернистской литературы. Наряду с такими хорошо известными атрибутами, как черный юмор, фантазии и мечты, фрагментация, элементы метапрозы, интертекстуальность, пародия, радикальная ирония, литература изобилует агрессивными нападками на то, что в разной степени может пониматься как постмодернистское общество. Эстетику социального протеста, выражаемого в отклонениях сексуального поведения, наркотической и алкогольной зависимости (Америка), проявлениях безумия и историческом упадке (Китай), следует понимать как чувство трагедии, тесно связывающее две иивилизации, которые ни на одном историческом этапе не были так похожи.

Ключевые слова: американская мечта, культурная революиия, маоизм, постмодерн, постмодернизм.

Научная специальность: 10.00.00 - филологические науки. 